Tropical Journal of Pharmaceutical Research March 2020; 19 (3): 661-666

ISSN: $1596-5996$ (print); 1596-9827 (electronic)

(C) Pharmacotherapy Group, Faculty of Pharmacy, University of Benin, Benin City, 300001 Nigeria.

\title{
Comparison of the efficacy of half ticagrelor loading doses and clopidogrel in elderly acute coronary syndrome patients in China
}

\author{
Jian Xue, Mingming Li, Lijie Wang, Minjun Ma, Jin Zhang* \\ Department of Cardiology, the Fifth Medical Center of Chinese PLA General Hospital, Beijing, China \\ *For correspondence: Email: Jin_Zhang_CA@yeah.net; Tel: +86-13331056690
}

Sent for review: 16 October 2018

Revised accepted: 26 February 2020

\begin{abstract}
Purpose: To evaluate the effects of half-load doses (HLD) of ticagrelor and clopidogrel on elderly acute coronary syndrome patients (ACS) over a period of 90 days.

Methods: Seventy-four patients diagnosed as ACS were included in this trial. The patients were randomly distributed into group 1 (treated with HLD ticagrelor, $90 \mathrm{mg} L D$ ) and group 2 (treated with clopidogrel, $300 \mathrm{mg}$ LD). The interaction of treatment effect was evaluated using Multivariate Cox proportional hazards regression models.

Results: Within three months, a total of 12 patients (16.21\%) died of myocardial infarction or stroke. The endpoint of HLD ticagrelor-treated elderly ACS patients was $20 \%$, and the incidence of clopidogreltreated endpoints was $14.81 \%$.

Conclusion: In the first 45 patients treated with HLD ticagrelor, their cumulative incidence of cardiac events was relatively high. However, there were no considerable changes in the therapeutic benefits of these two drugs in elderly ACS patients.
\end{abstract}

Keywords: Elder patients, Acute coronary syndrome, Ticagrelor, Clopidogrel

\begin{abstract}
This is an Open Access article that uses a fund-ing model which does not charge readers or their institutions for access and distributed under the terms of the Creative Commons Attribution License (http://creativecommons.org/licenses/by/4.0) and the Budapest Open Access Initiative (http://www.budapestopenaccessinitiative.org/read), which permit unrestricted use, distribution, and reproduction in any medium, provided the original work is properly credited.

Tropical Journal of Pharmaceutical Research is indexed by Science Citation Index (SciSearch), Scopus, International Pharmaceutical Abstract, Chemical Abstracts, Embase, Index Copernicus, EBSCO, African Index Medicus, JournalSeek, Journal Citation Reports/Science Edition, Directory of Open Access Journals (DOAJ), African Journal Online, Bioline International, Open-J-Gate and Pharmacy Abstracts
\end{abstract}

\section{INTRODUCTION}

Drug therapy can inhibit platelet aggregation, thereby weakening the formation of the thrombotic process, and is therefore critical in preventing complications after percutaneous coronary intervention $(\mathrm{PCl})$ acute coronary syndrome (ACS) [1].

P2Y12, an adenosine diphosphate (ADP) receptor is essential for stabilization of platelet aggregates. P2Y12 receptor antagonists perform a pivotal role in platelet function by inhibiting platelet aggregation caused by ADP. P2Y12 receptors located on the outside of platelets can be activated by ADP and significantly inhibit platelet aggregation and platelet function and prevent thrombosis.

Clopidogrel is $\mathrm{P} 2 \mathrm{Y} 12$ antagonist and it needs to be adapted to an active metabolite to constrain platelet function [2]. Ticagrelor is similar to thienopyridine but it does not need to be activated to inhibit platelets [3]. The binding site 
of ticagrelor differ from ADP, making it as an allosteric antagonist, and the blocking outcome can be reversed. The thienopyridine prodrug prasugrel irreversibly inhibits platelet function. Prasugrel is more potent than clopidogrel because it can be more effectively converted into active metabolite. However, under the primary $\mathrm{PCl}$ strategy, this drug is not more effective or safer than ticagrelor in preventing acute ischemic and hemorrhagic events in myocardial infarction [2]. Aspirin and P2Y12 receptor inhibitors (dual antiplatelet treatment) - remain the cornerstone of ACS treatment. The use of ticagrelor or clopidogrel was recommend by current guidelines $[4,5]$. In large clinical trials, ticagrelor was linked to a lower death risk after myocardial infarction (MI) and stroke as compared to clopidogrel treatment in ACS (MI-ST-elevation, MI-non ST-elevation and unstable angina) $[6,7]$. Ticagrelor, binding to the P2Y12-receptor rapidly and reversibly, is more potent than that of clopidogrel and clopidogrel has several drawbacks, including drug-drug interactions, poor metabolic activation and the target interaction irreversibility.

PLATO (a clinical trial-platelet inhibition and patient outcomes) showed no increase in the primary safety endpoint (PSE) for ticagrelor treatment and the secondary safety endpoint (SSE) was significantly increased after removing coronary artery bypass grafting (CABG), especially in elderly patient group [8]. Recent investigations have also indicated that the bleeding events related ticagrelor was higher outside clinical trials, and that its risk increases with age $[9,10]$. Unfortunately, these studies did not include patients in Asia. Previous studies suggest that Asian people treated by clopidogrel had higher active rates for metabolite and stronger pharmacodynamics responses than Caucasian [11]. Ticagrelor used in low doses was much potent for inhibition of platelet aggregation (IPA) in Korean healthy population [12]. The lower PSE using low ticagrelor doses and standard clopidogrel dose indicates that this population should be given lower drug doses to reduce bleeding events. This paper compared the effect of half loading dose (HLD) ticagrelor [90 $\mathrm{mg}$ followed by $45 \mathrm{mg}$ maintenance dose (MD) twice daily] with clopidogrel (300 mg followed by $75 \mathrm{mg}$ daily MD) on elder Chinese ACS patients.

\section{METHODS}

\section{Subjects}

This clinical trial for elder ACS subjects was a randomized, single-blind performed in a single- center from January to December 2016. A total of 97 subjects from Affiliated Hospital of Military Academy of Medical Sciences were included.

The inclusion criteria were: 1 . Patients age $\geq 75$ years old; 2. ACS [10]; 3. Patients did not take clopidogrel or ticagrelor at least 2 weeks. The exclusion criteria were: 1. Planned to use ADP receptor antagonists or anticoagulant treatment during the study period; 2 . Platelet count was < $0.1 \mathrm{~g} / \mathrm{mL}$; 3 . Kidney disease requiring dialysis; 4 . Cardiac shock; 5 . Severe congestive heart failure NYHA II - IV [(New York Heart Association), 13], 6 . The ejection fraction of left ventricular $<40 \%$; and 7. A bleeding tendency history.

\section{Study design}

Of the 97 patients included, 13 of them were outside the scope of this study. Ten patients refused to participate. A total of 74 people were included in this study. Figure 1 shows the flow chart of the study design. Table 1 shows the patients clinical features. The principles of Declaration of Helsinki were followed [14]. The ethics committee of the Affiliated Hospital of Military Academy of Medical Sciences Beijing, China) approved this trial (KY2015-315, dated on 03-24, 2015). Written informed consent was obtained from all participants.

The 74 patients were randomly divided into: Group 1: $90 \mathrm{mg}$ LD of ticagrelor (HLD, AstraZeneca) then MD $45 \mathrm{mg}$ twice daily for 90 days; Group 2: 300 mg of LD clopidogrel (Sanofi Winthrop Industries) then go by MD $75 \mathrm{mg}$ daily for 90 days. All patients received an aspirin (LD $300 \mathrm{mg}$ and MD $100 \mathrm{mg}$ ) according to institutional standards to complete the treatment planning and data collection.

During the entire treatment period, the patients were ordered to take medicines as planned at roughly the same time on their own (Figure 1). Researchers responsible for patient contact and endpoint measurements have no any information of drug distribution prior to completion of data collection.

\section{Definition of outcomes}

The primary outcome was assessed 90 days after treatment, including death, MI recurrence, or stroke. Bleeding events - intrapericardial bleeding with cardiac tamponade, intracranial bleeding, fatal bleeding, hypovolemic shock and the hemoglobin level $<5.0 \mathrm{~g}$ in elderly Chinese patients were compared to the major population [15]. 
Table 1: Demographics and baseline clinical characteristics of patients

\begin{tabular}{|c|c|c|c|}
\hline Characteristic & $\begin{array}{l}\text { Ticagrelor group } \\
(n=20, \mathrm{DI} \#=0.40)\end{array}$ & $\begin{array}{c}\text { Clopidogrel } \\
\text { group } \\
(n=54 \\
\text { DI\#=0.627) }\end{array}$ & P-value \\
\hline Age (yr) & & & 0.398 \\
\hline $75-79$ & 12 & 38 & \\
\hline $80-85$ & 5 & 13 & \\
\hline$>85$ & 3 & 3 & \\
\hline Gender & & & 0.702 \\
\hline women & 9 & 27 & \\
\hline men & 11 & 27 & \\
\hline Cardiovascular risk factor & & & \\
\hline Habitual smoker & 14 & 8 & 0.235 \\
\hline Hypertension & 5 & 40 & 0.935 \\
\hline Dyslipidemia & 7 & 9 & 0.089 \\
\hline Diabetes mellitus & 17 & 10 & 0.142 \\
\hline $\begin{array}{l}\text { Positive troponin I test of entry } \\
\text { level }\end{array}$ & 16 & 32 & 0.092 \\
\hline ACS & & & 0.001 \\
\hline MI-ST-elevation & 9 & 4 & \\
\hline MI-non ST-elevation & 7 & 28 & \\
\hline Unstable angina & 4 & 22 & \\
\hline Planned invasive management & & & 0.115 \\
\hline invasive & 9 & 14 & \\
\hline Non-invasive & 11 & 40 & \\
\hline
\end{tabular}

Note: \#DI: Distribution of index

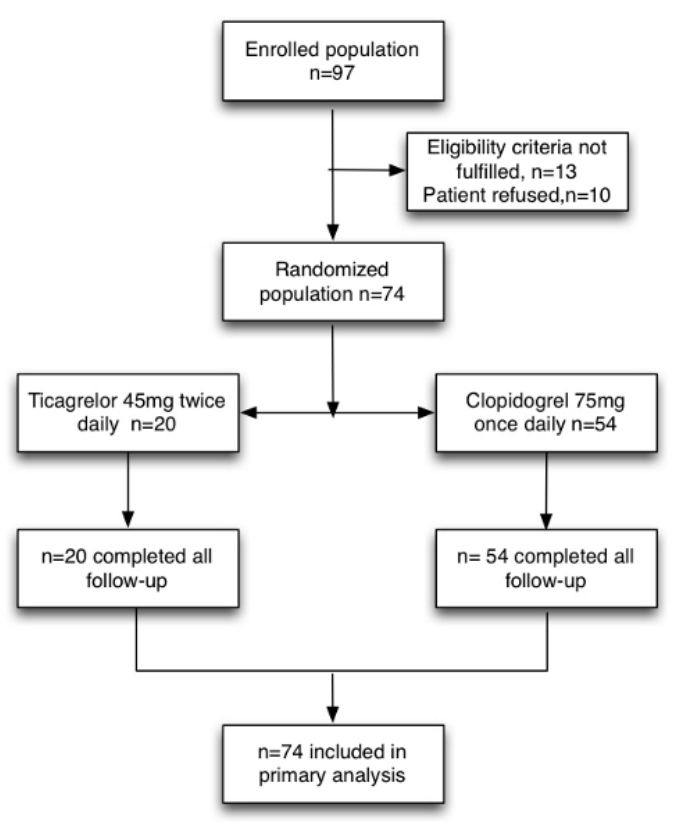

Figure 1: Flow diagram of the study design

\section{Data analysis}

Statistical significance of the baseline data between group 1 and group 2 were analyzed using $\mathrm{X}^{2}$ test. Survival was determined with Kaplan-Meier test. The time-event incidence from the initial date to the onset of the end point or censoring time was assessed. Stratified survival was analyzed based on the use of ticagrelor or clopidogrel.

The hazards of patients having HLD ticagrelor compared patients who received clopidogrel was calculated using Cox regression model with ticagrelor as a time-dependent variable. The variables were age, sex, cardiovascular risk factor, final diagnosis of ACS and planned invasive management. All analyses were carried out by Predictive Analytic Software (PASW) 20.0 (IBM Inc., Armonk, USA). $P<0.05$ was considered to be significant (Table 2).

\section{RESULTS}

Of the 74 subjects (including 38 men), the mean age was $79.12 \pm 3.03$ years. Of these, 12 patients $(16.21 \%)$ showed a composite endpoint (CE, stroke, myocardial infarction, and cardiovascular death within 90 days). The incidence of end-point was $20 \%$ in group 1 (HLD ticagrelor), $14.81 \%$ in group 2 (clopidogrel treatment). However, compared with clopidogrel, ticagrelor did not have a clear clinical advantage in the primary composite outcome.

The cumulative incidence of CE for the first 90 days of follow-up was presented in Figure 2. The analysis indicated that there was a elevated cumulative incidence of cardiac events in group 1 in the first 45 days than that in group 2, but not significant on day 45 and day 90 between two groups.

Trop J Pharm Res, March 2020; 19(3): 663 
Table 2: Cox proportional hazards model for evaluating factors associated with patients who received half loading dose ticagrelor treatment.

\begin{tabular}{|c|c|c|c|}
\hline Characteristic & $\begin{array}{l}\text { Hazard Ratio for } \\
\text { Ticagrelor group }\end{array}$ & $95 \% \mathrm{Cl}$ & $P$-value \\
\hline Age (yrs) & & & 0.767 \\
\hline $75-79$ & Ref & Ref & \\
\hline $80-85$ & 1.30 & $0.31-5.38$ & \\
\hline$>85$ & 2.12 & $0.28-16.0$ & \\
\hline gender & & & 0.78 \\
\hline $\begin{array}{l}\text { women } \\
\text { men }\end{array}$ & $\begin{array}{l}\text { Ref } \\
1.27\end{array}$ & $\begin{array}{c}\text { Ref } \\
0.24-6.82\end{array}$ & \\
\hline \multicolumn{4}{|l|}{$\begin{array}{l}\text { Cardiovascular } \\
\text { risk factor }\end{array}$} \\
\hline Habitual smoker & 1.42 & $0.34-5.93$ & 0.64 \\
\hline Hypertension & 2.54 & $0.46-13.9$ & 0.28 \\
\hline Dyslipidemia & 0.75 & $0.14-4.19$ & 0.75 \\
\hline Diabetes mellitus & 0.43 & $0.10-1.78$ & 0.24 \\
\hline Positive troponin I test of entry level & 0.78 & $0.16-3.78$ & 0.753 \\
\hline Final diagnosis of ACS & & & 0.565 \\
\hline MI- ST-elevation & Ref & Ref & \\
\hline MI-Non-ST-elevation & 1.25 & $0.20-7.91$ & \\
\hline Unstable angina & 0.48 & $0.05-4.75$ & \\
\hline Planned invasive management & & & 0.930 \\
\hline Non-invasive & Ref & Ref & \\
\hline Invasive & 1.06 & $0.28-4.07$ & \\
\hline
\end{tabular}

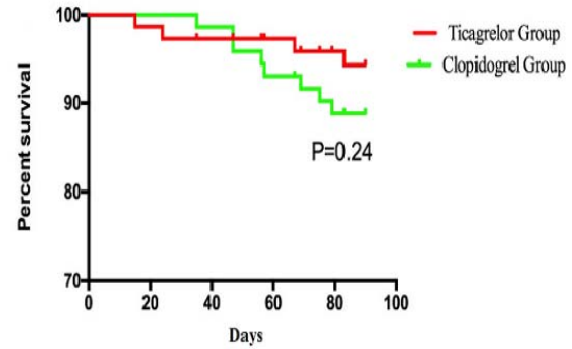

Figure 2: The cumulative incidence of the composite endpoint for the first 90 days of follow-up

\section{DISCUSSION}

The trial is the first study that compared PSE and SSE between HLD ticagrelor and clopidogrel in elderly ACS in Chinese. The new findings were: 1. During the 90 days follow-up time, there was no statistically change in the frequency of endpoint events between the groups 1 and 2; 2 . Patients with HLD ticagrelor treatment showed increases the incidence of end points in the first 45 days. 3 . HLD ticagrelor significantly reduces the bleeding events and none of them showed major bleeding events. The frequency of bleeding events in group 1 was even lower than those in group 2, but no considerably difference was observed between them. Thus, for elderly ACS patients, when compared to clopidogrel group, HLD ticagrelor had similar safety and slightly better efficacy. Above all, HLD ticagrelor may be a better choice based on the cumulative incidence of the composite end point for the first 90 days.
The use of acetylsalicylic acid and P2Y12receptor antagonist for the dual antiplatelet therapy is essential in treating ACS. Current practice guidelines recommended dual antiplatelet agents for 1 year after ACS, with the highest risk of thrombosis in the first 90 days [12, 16]. Therefore, the 90-day observations of this study suggest that clopidogrel is not the most effective antiplatelet drug because it has several disadvantages including drug-drug interactions, poor metabolic activation and the irreversibility of the target interaction. Ticagrelor acts directly on P2Y12 receptor antagonist. Based on the PLATO trial, ticagrelor has been proposed by current ACS guidelines [6]. PLATO shows that ticagrelor treatment significantly decreased the death percentage from of $\mathrm{Ml}$, stroke and vascular causes as compared with clopidogrel in ACS patients. Similar advantage was observed for death from $\mathrm{Ml}$ and various components of vascular causes. The beneficial consequences of ticagrelor were reached with no significant increase of major bleeding outcome [8].

When compared to the younger patients, elderly subjects have a higher risk of recurrent ischemic events, death and therapy-related complications [17-20]. Patients older than 75 years account for one-third of the total number of ACS episodes, which accounted for around $60 \%$ of total ACS mortality [21]. Age characteristics are risk factors for many stratification models of bleeding risk. In fact, bleeding risk is greater in elderly than in younger patients [22]. In this study, the end events among elder ACS patients was slightly

Trop J Pharm Res, March 2020; 19(3): 664 
higher than previous clinical trials [23]. In addition, the combination treatment of antiplatelet and anticoagulant may have a higher bleeding risk in the elderly, leading to a lower clinical net benefit of the treatment [15]. Age can be used as the predictor for intracranial hemorrhage when using antiplatelet or anticoagulant remedy [24].

For Asian ethnicity, HLD ticagrelor may be a better choice. Goo et al showed that in 12 healthy Korean subjects, ticagrelor (90 mg /LD then $90 \mathrm{mg} /$ day /MD for 5 days) had a faster and more effective IPA than clopidogrel $(600 \mathrm{mg} / \mathrm{LD}$ then $75 \mathrm{mg} /$ day/MD for 5 days) [11]. Previous clinical trial has revealed that the HLD ticagrelor (90 $\mathrm{mg} / \mathrm{LD}$, then $45 \mathrm{mg} / \mathrm{MD}$ twice daily) had comparable inhibition on platelet aggregation than standard ticagrelor dose $(180 \mathrm{mg} / \mathrm{LD}$ then $90 \mathrm{mg} / \mathrm{MD}$ twice daily), and it was considerably stronger than that of the clopidogrel therapy [25]. The ticagrelor $45 \mathrm{mg}$ tablet was not offered in our hospital and thus, the $90 \mathrm{mg}$ was therefore selected for this study.

\section{Limitations of the study}

The study had the following limitation: First, the sample size was small and the follow-up time was short and there was a lack of net benefit comparison of ACS patients such the ischemic events risk and bleeding events in different ages.

\section{CONCLUSION}

In Chinese ACS patients, HLD ticagrelor has similar safety and slightly better efficacy than those treated with clopidogrel. Future studies need to need to utilize greater sample size, longer follow-up time, and expand the study to patients with ACS at different ages.

\section{DECLARATIONS}

\section{Conflict of interest}

No conflict of interest is associated with this work.

\section{Contribution of authors}

We declare that this work was done by the authors named in this article and all liabilities pertaining to claims relating to the content of this article will be borne by the authors. JX designed the study and wrote 1st draft. JX and ML led the study. JX wrote this manuscript. LW and MM analyzed and interpreted the patient data. JZ participated in the investigation, critically revised the manuscript. All authors have approved the final version of this manuscript for publication.

\section{Open Access}

This is an Open Access article that uses a funding model which does not charge readers or their institutions for access and distributed under the terms of the Creative Commons Attribution License (http://creativecommons.org/licenses/by/ 4.0) and the Budapest Open Access Initiative (http://www.budapestopenaccessinitiative.org/rea d), which permit unrestricted use, distribution, and reproduction in any medium, provided the original work is properly credited.

\section{REFERENCES}

1. Damman $P$, Woudstra $P$, Kuijt WJ, de Winter RJ, James SK. P2Y12 platelet inhibition in clinical practice. $J$ Thromb Thrombolysis 2012; 33(2): 143-153.

2. Bundhun PK, Shi JX, Huang F. Head to head comparison of Prasugrel versus Ticagrelor in patients with acute coronary syndrome: a systematic review and metaanalysis of randomized trials. BMC Pharmacol Toxicol 2017; 18(1): 80.

3. David Royston. Anticoagulant and Antiplatelet Therapy. Pharmacology and Physiology for Anesthesia Hugh C. Hemmings, Jr. and Talmage D. Egan. 2012 Elsevier Inc, 2013; pp 643-667.

4. O'Gara PT, Kushner FG, Ascheim DD, Casey DE Jr, Chung MK, de Lemos JA, Ettinger SM, Fang JC, Fesmire FM, Franklin BA, et al. 2013 ACCF/AHA guideline for the management of ST-elevation myocardial infarction: a report of the American College of Cardiology Foundation/American Heart Association Task Force on Practice Guidelines Circulation. 2013; 127(4): e362-425.

5. Amsterdam EA, Wenger NK, Brindis RG, Casey DE Jr, Ganiats TG, Holmes DR Jr, Jaffe AS, Jneid H, Kelly RF, Kontos MC, et al. 2014 AHA/ACC guideline for the management of patients with non-ST-elevation acute coronary syndromes: executive summary: a report of the American College of Cardiology/American Heart Association Task Force on Practice Guidelines. Circulation 2014; 130(25): 2354-2394.

6. Berger JS. Aspirin, clopidogrel, and ticagrelor in acute coronary syndromes. Am J Cardio 2013; 112(5): 737745.

7. Johanne Silvain, Mathieu Kerneis, Gilles Montalescot Potent P2Y12 Inhibitors in Low-Risk Patients Journal of the American College of Cardiology 2016; 67(6): 614617.

8. Wallentin L, Becker RC, Budaj A, Cannon CP, Emanuelsson $\mathrm{H}$, Held C, Horrow J, Husted S, James S, Katus $H$, et al. Ticagrelor versus clopidogrel in patients with acute coronary syndromes. N Engl J Med 2009; 361: 1045-1057.

Trop J Pharm Res, March 2020; 19(3): 665 
9. Capodanno D, Angiolillo DJ. Pretreatment with antiplatelet drugs in invasively managed patients with coronary artery disease in the contemporary era: review of the evidence and practice guidelines. Circ Cardiovasc Interv 2015; 8: e002301.

10. Roffi $M$, Patrono $C$, Collet JP, Mueller $C$, Valgimigli $M$, Andreotti F, Bax JJ, Borger MA, Brotons C, Chew DP, et al. 2015 ESC guidelines for the management of acute coronary syndromes in patients presenting without persistent ST-segment elevation. Eur Heart J 2016; 37: 267-315.

11. Guo LZ, Kim MH, Jin CD, Lee JY, Yi SJ, Park MK, Cho $Y R$, Park TH. Comparison of pharmacodynamics between low dose ticagrelor and clopidogrel after loading and maintenance doses in healthy Korean subjects. Platelets 2015; 26(6): 563-569.

12. Franchi $F$, Rollini $F$, Cho JR, Bhatti $M$, DeGroat $C$, Ferrante $E$, Dunn EC, Nanavati A, Carraway $E$, Suryadevara $S$, et al. Impact of escalating loading dose regimens of ticagrelor in patients with ST-segment elevation myocardial infarction undergoing primary percutaneous coronary intervention: results of a prospective randomized pharmacokinetic and pharmacodynamics investigation. J Am Coll Cardio Intv 2015; 8: 1457-1467.

13. The Criteria Committee of the New York Heart Association. Functional Capacity and Objective Assessment. M. Dolgin (Ed.), Nomenclature and criteria for diagnosis of diseases of the heart and great vessels (9th ed.), Little, Brown and Company, Boston, MA, USA, 1994, pp. 253-255.

14. Declaration of Helsinki. Ethical principles for medical research involving human subjects. J Indian Med Assoc 2009; 107(6): 403-405.

15. Husted S, James S, Becker RC, Horrow J, Katus $H$, Storey RF, Cannon CP, Heras M, Lopes RD, Morais J, et al PLATO study group. Ticagrelor versus clopidogrel in elderly patients with acute coronary syndromes: a sub study from the prospective randomized PLATelet inhibition and patient Outcomes (PLATO) trial. Circ Cardiovasc Qual Outcomes 2012; 5(5): 680-688.

16. Steen Husted, Stefan James, Richard C. Becker. Ticagrelor versus Clopidogrel in Elderly Patients with Acute Coronary Syndromes Circ Cardiovasc Qual Outcomes 2012; 5: 680-688.
17. Sohita Dhillon. Ticagrelor: A Review of Its Use in Adults with Acute Coronary Syndromes. Am J Cardiovasc Drugs 2015; 15(1): 51-68.

18. Ferri N, Corsini A, Bellosta S. Pharmacology of the new P2Y12 receptor inhibitors: insights on pharmacokinetic and pharmacodynamic properties. Drugs 2013; 73: 1681-1709.

19. Levine GN, Jeong YH, Goto S, Anderson JL, Huo Y, Mega YJ, Taubert K, Smith Jr SC. Expert consensus document: World Heart Federation expert consensus statement on antiplatelet therapy in East Asian patients with ACS or undergoing PCI. Nat. Rev. Cardiol 2014; 11 (10): 597-606.

20. He MJ, Liub $B$, Sunb $D H$. One-quarter standard-dose ticagrelor better than standard-dose clopidogrel in Chinese patients with stable coronary artery disease: $A$ randomized, single-blind, crossover clinical study. International Journal of Cardiology 2016; 215: 209-213.

21. Bhatt $D L$, Flather $M D$, Hacke $W$, et al. Patients with prior myocardial infarction, stroke, or symptomatic peripheral arterial disease in the CHARISMA trial. J Am Coll Cardiol 2007; 49: 1982-1988.

22. Task Force Members, Montalescot G, Sechtem U, Achenbach S, Andreotti F, Arden C, Budaj A, Bugiardini $R$, Crea F, Cuisset T, Di Mario C, et al. 2013 ESC guidelines on the management of stable coronary artery disease: the Task Force on the management of stable coronary artery disease of the European Society of Cardiology. Eur Heart J 2013; 34: 2949-3003.

23. Bonaca MP, Bhatt $D L$, Cohen $M$, Steg PG, Storey RF, Jensen EC, Magnani G, Bansilal S, Fish MP, Im K, et al. Long-term use of ticagrelor in patients with prior myocardial infarction. N Engl J Med 2015; 372: 17911800.

24. Angiolillo DJ, Franchi F, Waksman R, Sweeny JM, Raveendran G, Teng R, Zhao Y, Carlson G, Khan N, Mehran R. Effects of Ticagrelor Versus Clopidogrel in Troponin-Negative Patients With Low-Risk ACS Undergoing Ad Hoc PCl. J Am Coll Cardiol 2016; 67(6): 603-613.

25. Xue HJ, Shi J, Liu B, Wang DY, Dong ZX, Guo H, Kong $Y H$, Sheng $L$, Shao $Q$, Sun $D H$, et al. Comparison of half- and standard-dose ticagrelor in Chinese patients with NSTEACS. Platelets 2016; 2: 1-6. 